\title{
Study on Industrial Structure Adjustment of Fuxianhu Waterside Based on Water Environment Carrying Capacity
}

\author{
Xianhua Wu ${ }^{1,}$, Jichang Wu ${ }^{2}, K_{e}$ Deng $^{3}$, Hong Chen ${ }^{1}$, and Yue Wang ${ }^{1}$ \\ ${ }^{1}$ Yuxi Research Center for Eco- Environmental Sciences on Plateau Lakes, Yuxi Normal University, Yuxi \\ Yunnan, 653100, China \\ ${ }^{2}$ Yuxi fuxian lake authority, Yuxi Yunnan, 653100, China \\ ${ }^{3}$ Yuxi Fuxian Lake Protection Development Investment Company, LTD, Yuxi Yunnan, 653100, China \\ *Corresponding author
}

Keywords: Water environment, Industrial organization, Carrying Capacity

\begin{abstract}
The Fuxian Lake is the largest deep-water freshwater lake in China and is a typical representative of poorly-nourished lake. With the rapid population growth in the lake basin and the accelerating urbanization, eutrophication is threatening the health of the lake. Aiming at the characteristics of poorly-nourished lakes in Fuxian Lake, the paper, based on the carrying capacity of the water environment, focuses on the reduction of the main pollutants emission into the lake, according to the principle from easy to difficult and first things first. Under the guidance of the idea of "one return, two adjustments and three conservations", the paper emphasizes the lake buffer zone and the northern pollution control area of the lake. There have been the treatment key pollution sources along the lake in the Fuxian Lake Basin. The buffer zone retreat and ecological construction, the industrial structure adjustment of the dam area, the green ecological construction of the mountainous and semi-mountainous areas, the control of the water pollution of rivers into the lake and the restoration of the mechanism of fresh water production, and the construction of an integrated river basin management system are established so as to fundamentally reduce the amount of pollutants produced and the amount of water entering, so the water quality's decline trend has been restrained and the basin ecological environment has been improved significantly. Therefore, the sustainable social and economic development of the basin has achieved and the water environment quality of Fuxian Lake has been maintained steadily.
\end{abstract}

\section{Research methods}

Collect data and literature, including the statistical yearbooks, policies and regulations, the "Twelfth Five-Year Plan" for water pollution control in the Fuxian Lake Basin, and relevant research results, etc. Effectively screen, compare and analyze the Fuxian Lake Basin-related data of economic and social development.

In view of the recent water pollution in the Fuxian Lake, the main socioeconomic driving factors influencing the carrying capacity of water environment in the lake have been screened. The socioeconomic development of a pollutant discharge and the health of the water environment system have been considered. Also, the relationship between the system and sustainable socio-economic development in the basin has been studied.

\section{Results and discussion}

\subsection{The Water Pollution Control Philosophy of the Fuxian Lake}

In view of the characteristics of the poorly-nourished lake in Fuxian Lake, based on the water environment carrying capacity, focusing on the emission reduction of the main pollutants into the lake, starting from the whole basin, taking "one return, two transfers and three conservations" as 
strategic decision-making, the new conception of Fuxian protection and prevention with the principle of "controlling source has been adopted, with the content of "systematic source control - the restoration of the mechanism of fresh water production - lake water protection and conservation enhanced management of the watershed". Form a complete prevention and control system of water pollution in the poorly-nourished lake with the main content of "prevention first, prudent development and construction of green watershed" so as to achieve sustainable socio-economic development of the river basin and steadily maintain the water environment quality of the Fuxian Lake.

One return: is the implementation of the project of "three returns" within a range of 100 meters from the Fuxian Lake Class I Reserve above 1722.5 meters, resolutely returning ponds, fields and buildings to the lake. Two adjustments: is to adjust the primary, secondary and tertiary industries from the outer Fuxian Grade I Reserve to the altitude of 1,900 meters. Remove all the secondary industries from the region; encourage the primary industry to mainly develop high quality, suitable and efficient forest and fruit industry, and meanwhile develop policies to encourage farmers to apply organic fertilizer; introduce high-end, non-polluting, strong large-scale enterprises in the tertiary industry; three insurance: is to strengthen ecological protection on the mountains or mid-levels above 1900 meters, so as to protect the existing woodland and original tree species.

\subsection{The Division of the Water Pollution Control in the Fuxian Lake}

In view of the Fuxian Lake's poor-nutrition, good-quality, healthy aquatic ecology characteristics and the long-term requirements of sustainable development of the basin and the potential environmental impact of social and economic development, aiming at the maintenance of lake water ecological health, focusing on the total amount of pollutants emissions reduction, take measures to reduce key sources first; increase the intensity of governance in heavily polluted areas; strengthen watershed monitoring and management and establish the three water environment management system and mode consisting of watersheds, control areas and control units to achieve comprehensive reduction of pollutants. According to the distribution characteristics of the pollution sources in the Fuxian Lake, divide the Fuxian Lake and its drainage basin to lay the foundation for the prevention and control of zoning and the design of more targeted prevention and control programs. According to the topographic features, pollution status and pollution load in the Fuxian Lake Basin, considering the socio-economic factors and pollutant discharge characteristics, taking the lake as a core and the bank as a baseline, five major functional areas surrounding the lake and water body are formed, with prescribed development limits for each area. The Fuxian Lake Basin is divided into seven pollution prevention and control areas: I: Northern Key Pollution Prevention and Control Area (183.6 km2); II: Southern Key Pollution Prevention and Control Area (36.5 km2); III: Fuxian Primary Reserve (9.1 km2); IV: Northeastern Phosphate Pollution Control Area (55.9 km2); V: Western Tourism Pollution Control Area (27.6 km2); VI: Eastern Soil Erosion Control Area (67.8 km2); VII: Independent Control Area (i.e. Development Prohibition Control Area 59.6 km2) and Maotianshan Ecological Environment Protection Area (18 km2).

\subsection{Analysis of Major Environmental Problems in Different Pollution Prevention and Control Areas}

According to the survey of the pollution sources and the regional characteristics of the pollution prevention and control areas in the Fuxian Lake (see Table 1), the water environmental carrying capacity of the pollution prevention and control area in the northern part of the Fuxian Lake Basin accounts for one third of the total carrying capacity of the Fuxian Lake. The farmland runoff pollution in the area accounts for $50 \%$ of the total farmland runoff pollution in the basin. The domestic sewage and the manure and livestock excrement in the village account for $57 \%$ of the rural pollution in the whole basin. Therefore, this area is the key area for the whole basin management. 
Table 1. The Characteristics of the Fuxian Lake Pollution Prevention and Control Area

\begin{tabular}{|c|c|c|c|}
\hline Area Name & Area Coveage & Area Characteristics & $\begin{array}{c}\text { Major Environmental } \\
\text { Problems }\end{array}$ \\
\hline $\begin{array}{l}\text { Northern } \\
\text { Key Pollution } \\
\text { Prevention } \\
\text { Control Area }\end{array}$ & $\begin{array}{l}\text { Feng Lu and Longjie } \\
\text { in Chengjiang County }\end{array}$ & $\begin{array}{c}\text { Located in the dam area in the northern part of the } \\
\text { Fuxian Lake, it is a small basin of its main stream } \\
\text { entering the lake and the major industrial and } \\
\text { agricultural area in Chengjiang County. It has severe } \\
\text { pollution of industrial source, urban domestic sewage } \\
\text { and farmland runoff and is the main emission area of the } \\
\text { Fuxian Lake. }\end{array}$ & $\begin{array}{l}\text { Farmland runoff pollution } \\
\text { Urban sewage pollution } \\
\text { River pollution into the lake } \\
\text { Industrial source pollution }\end{array}$ \\
\hline $\begin{array}{l}\text { Southern } \\
\text { Key Pollution } \\
\text { Prevention } \\
\text { Control Area }\end{array}$ & $\begin{array}{c}\text { Road Town } \\
\text { in Jiangchuan County }\end{array}$ & $\begin{array}{l}\text { It is located in the dam area in the southern part of } \\
\text { Fuxian Lake. The main pollution includes the pollution } \\
\text { caused by towns and villages, the runoff pollution from } \\
\text { farmland and the phosphorous pollution in the upstream } \\
\text { Yangliuba mining area. The pollutants are input from } \\
\text { the two rivers, Luju River and Carassius auratus River. }\end{array}$ & $\begin{array}{l}\text { Urban sewage pollution } \\
\text { Farmland runoff pollution } \\
\text { Phosphate \& its chemical } \\
\text { pollution } \\
\text { Pollution of rivers into lake }\end{array}$ \\
\hline $\begin{array}{c}\text { The Fuxian Primary } \\
\text { Reserve }\end{array}$ & $\begin{array}{l}\text { The Fuxian Lake area } \\
\text { within } 100 \mathrm{~m} \text { above } \\
\text { 1722.5m of water line }\end{array}$ & $\begin{array}{l}\text { The district is closely linked with all districts, whose } \\
\text { pollutants finally enter the lake through Lake District. } \\
\text { The buffer zone along the lake is the last barrier for } \\
\text { pollutants into the lake. }\end{array}$ & $\begin{array}{l}\text { The occupied lake belt } \\
\text { The artificial reformed lake } \\
\text { belt } \\
\text { Tourism, farmland and other } \\
\text { pollution directly into the lake }\end{array}$ \\
\hline $\begin{array}{c}\text { Northeastern } \\
\text { Phosphate Pollution } \\
\text { Control Area }\end{array}$ & $\begin{array}{c}\text { Part of Yousuo, Jiucun, } \\
\text { Haikou and Xincun in } \\
\text { Chengjiang County }\end{array}$ & \begin{tabular}{|} 
Located in the northeast of Fuxian Lake, it is the main \\
production area of phosphate chemical industry. The \\
area has poor vegetation. Due to the exploitation of \\
phosphate rock, the landform is seriously destructed, \\
with severe soil erosion and a large amount of sediment \\
with high phosphate content entering the lake, \\
threatening the water environment of the Fuxian Lake.
\end{tabular} & $\begin{array}{l}\text { Phosphate mining area } \\
\text { pollution } \\
\text { Phosphate chemical plants } \\
\text { pollution } \\
\text { Soil Erosion }\end{array}$ \\
\hline $\begin{array}{l}\text { Western } \\
\text { Tourism } \\
\text { Pollution } \\
\text { Control Area }\end{array}$ & $\begin{array}{l}\text { Part of Jiangcheng in } \\
\text { Jiangchuan County }\end{array}$ & $\begin{array}{l}\text { Located in the West Bank of the Fuxian Lake, it is the } \\
\text { main scenic tourism spot. Due to the construction of } \\
\text { tourist attractions and bad management of resorts, the } \\
\text { coastal water in the Lakeshore area is polluted; } \\
\text { mountain mining and other activities in the mountain } \\
\text { area have caused some damage to the natural landscape. }\end{array}$ & $\begin{array}{l}\text { Farmland pollution } \\
\text { Rural pollution } \\
\text { Tourism pollution } \\
\text { Vegetation Damage }\end{array}$ \\
\hline $\begin{array}{l}\text { Eastern } \\
\text { Soil Erosion } \\
\text { Control Area }\end{array}$ & $\begin{array}{l}\text { Part of Haiguan and } \\
\text { Haijing in Huaning } \\
\text { County, \& Luju in } \\
\text { Jiangchuan County }\end{array}$ & $\begin{array}{c}\text { It is located in Fuxian Lake East Bank, with high } \\
\text { mountain, steep slopes, seriously damaged vegetation, a } \\
\text { large amount of soil erosion and sediment into the } \\
\text { Fuxian Lake. }\end{array}$ & $\begin{array}{c}\text { Soil and water loss } \\
\text { Vegetation Damage } \\
\text { Steep slope reclamation }\end{array}$ \\
\hline \multirow{2}{*}{$\begin{array}{l}\text { Independent } \\
\text { Control Area }\end{array}$} & \begin{tabular}{|c|} 
Jiangchuan NiuMu \\
Pumping Station - \\
ChengJiangluFishing \\
Fish TailBar Area, \\
Jiangchuan \\
RoadHuhaiSea \\
Pumping Station - \\
HuaNing \\
HaiZhouTangZiCun \\
Pumping Station Area, \\
Jiangchuan Meyoung \\
Bay - Doushantouhe \\
Area \\
\end{tabular} & \begin{tabular}{|} 
Jiangchuan NiuMu Pumping Station - ChengJianglu \\
Fishtail Hill Area (Cattle - Fish Area): The lakeshore is \\
10.6km long and the control area is 36km2. Jiangchuan \\
Road is located at the East Sea Side Pumping Station - \\
Hua Ning Haiguang Tangzi Village pumping station \\
Area: Line length $16.7 \mathrm{~km}$, control area 44km2, \\
Jiangchuankou Bay - broken mountain Gehe area: lake \\
shoreline length 6.5km, control area 18.6km2.
\end{tabular} & $\begin{array}{l}\text { Ecology is still good } \\
\text { Less man-made destruction } \\
\text { District planning for limited } \\
\text { development }\end{array}$ \\
\hline & $\begin{array}{c}\text { Maoianshan Reserve of } \\
18 \mathrm{~km} 2\end{array}$ & $\begin{array}{l}\text { Since the total closure of phosphate rock mining in } \\
\text { 2004, potential environmental risks have and will persist } \\
\text { for a long time, and the "three wastes" pollution caused } \\
\text { by the production of phosphorus chemical productsis } \\
\text { difficult to cure in the short term. Now that it has } \\
\text { successfully become the World Heritage area, its } \\
\text { governance should be to create a world-renowned } \\
\text { tourist brand with a good ecological environment. }\end{array}$ & $\begin{array}{l}\text { Phosphate rock mining } \\
\text { damaged the vegetation; } \\
\text { Maotianshan ancient fossil } \\
\text { group is in the district }\end{array}$ \\
\hline
\end{tabular}




\subsection{The Allocation of the Carrying Capacity of the Fuxian Lake water environment}

Select the above seven areas except the Fuxian Lake Primary Reserve and carry out the division of the carrying capacity of water environment.

The water environmental carrying capacity of Fuxian Lake under the water quality protection targets of Category I is 20067.5t / a, 821.9t / a and 115.8t / a, respectively, and 11 generalized "entry points to the lake" are calculated Water environment carrying capacity. In order to maintain the water quality of Fuxian Lake in Class I, the water environmental carrying capacity of Fuxian Lake is allocated to the corresponding inlet of each control zone according to the water environmental carrying capacity of 11 "entering the lake" and the designated pollution control areas, and get water environment carrying capacity of different water pollution control areas, with the results shown in Table 2. The amount of all pollutants entering the lake beyond its carrying capacity is the amount of pollutant reduction in each pollution control area.

Table 2. Water environmental carrying capacity in each water pollution control areas of the Fuxian Lake

\begin{tabular}{|c|c|c|c|c|c|c|}
\hline \multirow{2}{*}{ Number } & \multirow{2}{*}{ Goal } & \multicolumn{2}{|c|}{$\begin{array}{c}\text { Main pollutants lake water environment carrying } \\
\text { capacity (t/a) }\end{array}$} \\
\hline I & Class I & $\begin{array}{c}\text { Northern Key Pollution Prevention } \\
\text { and Control Area }\end{array}$ & 183.6 & 7291.9 & 309.6 & 40.8 \\
\cline { 5 - 7 } II & Class I & $\begin{array}{c}\text { Southern Key Pollution Prevention } \\
\text { and Control Area }\end{array}$ & 36.5 & 939.9 & 41.3 & 4.8 \\
\hline IV & Class I & $\begin{array}{c}\text { Northeastern Phosphate Pollution } \\
\text { Control Area }\end{array}$ & 55.9 & 2187.2 & 90.4 & 11.3 \\
\hline V & Class I & $\begin{array}{c}\text { Western Tourism Pollution Control } \\
\text { Area }\end{array}$ & 27.6 & 2362.9 & 113.4 & 13.5 \\
\hline VI & Class I & Eastern Soil Erosion Control Area & 67.8 & 2523.7 & 80.1 & 15.2 \\
\hline VII & Class I & Independent Control Area & 77.6 & 4760.1 & 187.1 & 30.2 \\
\hline
\end{tabular}

\subsection{Optimization and Adjustment of Industrial Structure in the Fuxian Lake Basin}

\subsubsection{Ideas of Optimization and Adjustment of Industrial Structure}

The proportion of the primary industry in the Fuxian Lake Basin is too large, and the traditional agriculture is especially obvious. The secondary industry is mainly composed of phosphate chemical industry, building materials and agricultural products processing, with small scale, extensive production and processing, single product structure and few high value-added products, without labor-intensive advantage industries, so that it cannot promote the development of other industries; the tertiary industry slowly develops, which mainly consists of catering and doesn't have obvious promotion for agriculture, processing industry, commerce and urban construction.

The adjustment idea of the industrial structure in the basin is: Based on the premise of meeting the carrying capacity of water environment of the Fuxian Lake water environment, through the optimization and adjustment of the industrial structure of the basin, form a benign industrial structure of "strengthening the tertiary industry, optimizing the primary industry and perfecting the secondary industry", reduce the discharge of pollutants from the source in the whole basin, promote and ensure the rapid development of a recycling economy in the basin. Build a low-carbon economy throughout the basin to encourage clean production and recycling economy to develop in a synchronized manner, focus on the combination of agricultural water and fresh water production mechanisms to fully utilize 
and allocate the carrying capacity of limited water environment and enhance the utilization of water environment carrying capacity effectiveness.

\subsubsection{The Optimization and Adjustment Program and Layout of Industrial structure}

(1) The Optimization and Adjustment Program and Layout of Agriculture and Forestry Industrial Structure

In the adjustment of agricultural structure, pay attention to the introduction of a green, organic and ecological three-dimensional agriculture model, the development of green agriculture bases, the cultivation of fine vegetables, green rice and organic agricultural products, the replacement of traditional farming with ecological agriculture, the vigorous development of high quality varieties, the optimization of the structure of varieties of agricultural products and the improvement of the quality of agricultural products; concentrate the layout of agricultural structures; focus on the implementation of inefficient forest rebuilding, the construction of water conservation forests and the improvement of the quality of forest products in the watersheds; integrate aquaculture into agriculture and forestry to form a circular economy mode of "livestock - biogas - fruit", adjust the layout of animal husbandry, and achieve the centralized layout of livestock husbandry with intensive and large-scale operation.

The development of agriculture industry in Fuxian Lake Basin is divided into four sections: green agriculture section, sightseeing agriculture section, three-dimensional agriculture section and leisure agriculture section.

(2) The Optimization and Adjustment of Industrial Structure

Following the water pollution prevention and control principle of "one return, two adjustments and three conservations", and the function division principle of "one body and four areas", insist on the theory of circular economy and eco-industrial concept, adjust the industrial structure based on the environmental carrying capacity of the lake and the general idea of " reducing pollution in the area and transferring it to other areas "and" industrial park", to ultimately achieve total pollutant control and the dynamic balance of the environmental capacity.

(3) The Optimization and Adjustment of Tourism Industry

The adjustment of tourism industrial structure is based on resort and recreation of lakes and resorts to deep lakes and ethnic culture as the foundation to develop ecologically-friendly tourism industry, strengthen and improve brand building, and form the tourism destination of the Fuxian Lake Recreation and Leisure Resort. Make the tourism in the basin a new point of economic growth and a new force for promoting the development of the tourism industry in Yunnan. Form the layout of one body and four areas, plus two cities, three towns and four themes in the Fuxian Lake basin.

"One body and four areas" means the lake water body, the lake buffer zone, restricted development area, green industrial area and water conservation area. "Two cities and three towns" refers to the formation of two tourist cities (Chengjiang county and Jiangchuan county) and three types of tourist towns (resource-oriented tourist towns, tourist reception-type tourist towns and ecologically-friendly tourist towns). "Four themes" refers to the division of the Fuxian Lake tourism: The Fuxian North caost Entertainment and Convention and Exhibition Area, the Fuxian West Coast Scenic and Historical and Cultural Tourism Area, the Fuxian East Coast Village Experience and Sports Tourism Area, the Fuxian South Coast folk and holiday tourism.

\section{Summary}

By analyzing the impact and degree of major industries on lake pollution in Fuxian Lake Basin, based on the water environmental carrying capacity, focusing on the emission reduction of the main pollutants into the lake, starting from the whole basin, according to the strategic decision of "one return" and "two adjustments" and "three conservations", and the new concept of protection and prevention of the Fuxian Lake of "systematic source control - the restoration of the mechanism of fresh water production - lake water protection and conservation - enhanced management of the watershed", form a complete prevention and control system of water pollution in the 
poorly-nourished lake with the main content of "prevention first, prudent development and construction of green watershed", to achieve sustainable social and economic development of the basin and steadily maintain the water environment quality of the Fuxian Lake.

\section{Acknowledgement}

This research was financially supported by the Yunnan University Science and Technology Innovation Team Support Program (IRTSTYN201422).

\section{References}

[1] Xiong Fei. Influence of Human Activities on the Fuxian Lake Ecosystem and Countermeasures for Protection, Anhui Agricultural Science,2009,37(14): 6584-6586.

[2] Jin Chunyan, Zhang Xiumin, Zhao Xianghua. Analysis on the Changing Tendency of Water Quality in the Fuxian Lake, Yunnan Environmental Science, 2004,23: 110-111. 